\title{
In-Line Monitoring of Effluents from HTGR Fuel Particle Preparation Processes Using a Time-of-Flight Mass Spectrometer
}
D. A. Lee
D. A. Costanzo
D. P. Stinton
J. A. Carpenter
W. T. Rainey, Jr.
D. C. Canada
J. A. Carter 


\section{DISCLAIMER}

This report was prepared as an account of work sponsored by an agency of the United States Government. Neither the United States Government nor any agency Thereof, nor any of their employees, makes any warranty, express or implied, or assumes any legal liability or responsibility for the accuracy, completeness, or usefulness of any information, apparatus, product, or process disclosed, or represents that its use would not infringe privately owned rights. Reference herein to any specific commercial product, process, or service by trade name, trademark, manufacturer, or otherwise does not necessarily constitute or imply its endorsement, recommendation, or favoring by the United States Government or any agency thereof. The views and opinions of authors expressed herein do not necessarily state or reflect those of the United States Government or any agency thereof. 


\section{DISCLAIMER}

Portions of this document may be illegible in electronic image products. Images are produced from the best available original document. 
Printed in the United States of America: Available from National Technical Information Service

U.S. Department of Commerce

5285 Port Royal Road, Springfield, Virginia 22161

Price: Printed Copy $\$ 4.00$; Microfiche $\$ 2.25$

This report was prepared as an account of work sponsored by the United States Government. Neither the United States nor the Energy Research and Development Administration/United States Nuclear Regulatory Commission, nor any of their employees, nor any of their contractors, subcontractors, or their employees, makes any warranty, express or implied, or assumes any legal liability or responsibility for the accuracy, completeness or usefulness of any information, apparatus, product or process disclosed, or represents that its use would not infringe privately owned rights. 
ORNL/TM-5579

Dist. Category UC-77

Contract No. W-7405-eng-26

ANALYTICAL CHEMISTRY DIVISION

THORIUM UTILIZATION PROGRAM (189a OHO45)

Fuel Refabrication Development - Task 210

IN-LINE MONITORING OF EFFLUENTS FROM HTGR FUEL PARTICLE PREPARATION PROCESSES USING A TIME-OF-FLIGHT MASS SPECTROMETER

D. A. Lee

D. A. Costanzo

D. P. Stinton*

J. A. Carpenter*

W. T. Rainey, Jr.

D. C. Canada

J. A. Carter

* Metals and Ceramics Division

August 1976

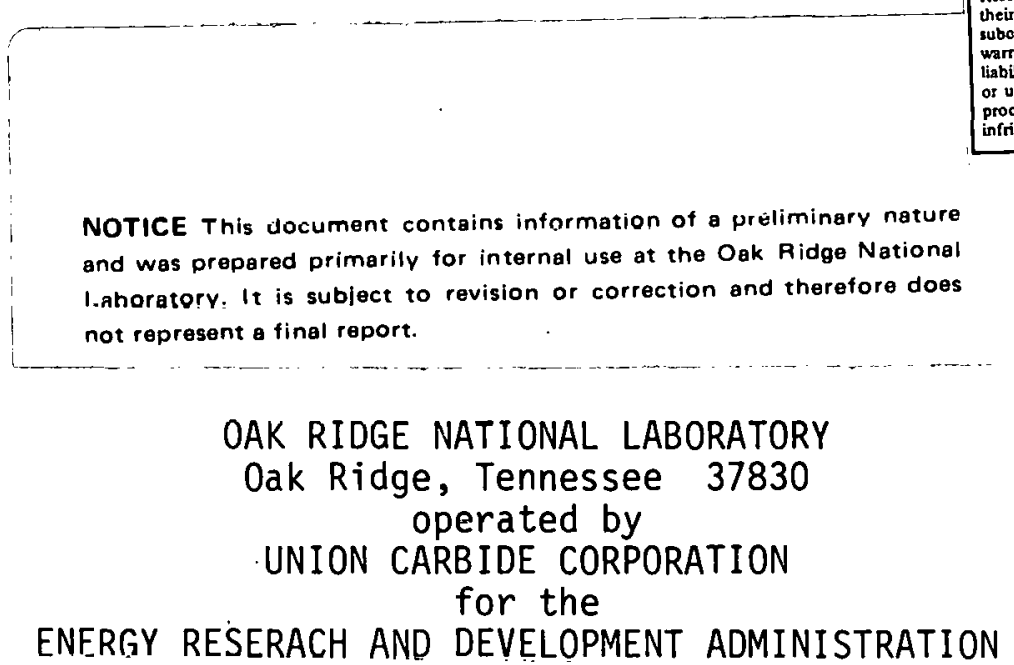

This seport was prepared as an account of work Thensored by the United States Governmeni. Neither the United States not the United States Energy

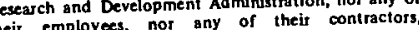
subcontractors, or their employees. makes any warmanty, express of implied, or assumes any legal

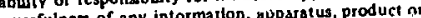
or usefulness of sny intormathon, app as wo would not process disclosedy owned tights.

NOTICE This document contains information of a preliminary nature and was prepared primarily for internal use at the Oak Ridge Nationa end is sublect to revision or correction and therefore does a final report.

OAK RIDGE NATIONAL LABORATORY

Oak Ridge, Tennessee 37830

operated by 
THIS PAGE

\section{WAS INTENTIONALLY \\ LEFT BLANK}




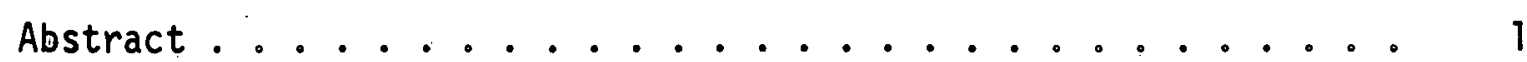

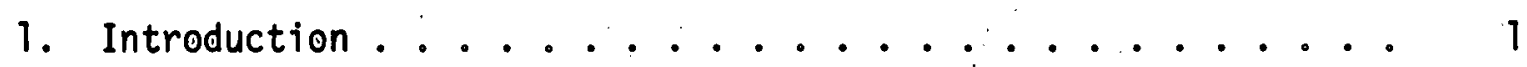

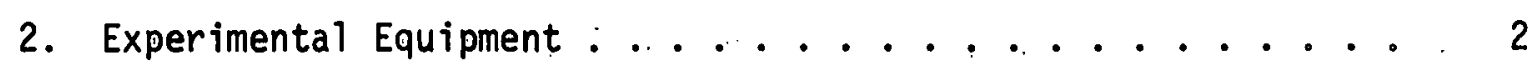

3. Experimental Materials and Process Procedures ....... 4

4. Results and Discussion ................ 7

4.1 Carbonization ................... 7

4.2 Conversion ..................... 11

4.3 Coating ....................... 12

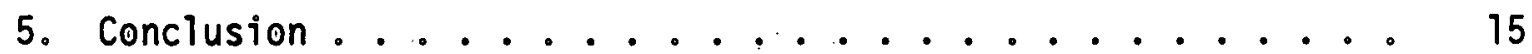

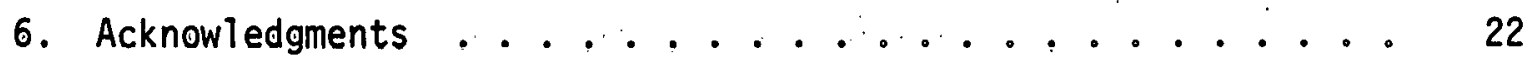

7. References ................... 23 
iv $\quad \cdots, \quad \ldots$

LIST OF FIGURES

Page

Figure 1. Gas Sampling Transfer Lines from Fuel Particle Coating Facility to TOFMS

17

Figure 2. $\mathrm{H}_{2} \mathrm{O}$ Evolution in Carbonization of Uranium-Loaded Weak Acid Resin ................ 18

Figure 3. Carbonization of Uranium-Loaded Weak Acid Resin .... 19

Figure 4. CO Evolution in Conversion of Uranium-Loaded Weak Acid Resin ................... 20

Figure 5. Evolution of Some Acetylene Pyrolysis Products during

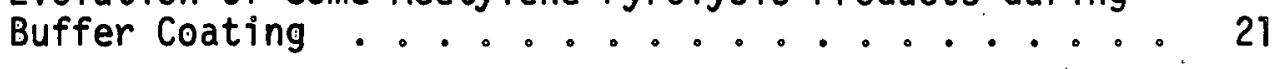


IN-LINE MONITORING OF EFFLUENTS FROM HTGR FUEL PARTICLE

PREPARATION PROCESSES USING A TIME-OF-FLIGHT MASS SPECTROMETER

D. A. Lee

B. A. Costanzo

D. P. Stintion*

J. A. Carpenter*

W. T. Rainey, Jr.

D. C. Canada

J. A. Carter

\section{ABSTRACT}

The carbonization, conversion, and coating processes in the manufacture of HTGR fuel particles have been studied with the use of a time-of-flight mass spectrometer. Non-condensable effluents from these fluidized-bed processes have been monitored continuously from the beginning to the end of the process. The processesi, which have been moritored are these: uranium-loaded ion exchange resin carbonization, the carbothermic reduction of $\mathrm{UO}_{2}$ to $U C_{2}$, buffer and low temperature isotropic pyrocarbon coatings of fuel kernels, SiC coating of the kernels; and high temperature particle annealing. Changes in concentrations of significant molecules with time and temperature have been useful in the interpretation of reaction mechanisms and optimization of process procedures.

\section{INTRODUCTION}

The reference recycle fuel for the HTGR consists basically of two types of microspheres: a Triso-coated fissile particle and a Biso-coated fertile particle. Triso-coated particles contain a kernel of $U \theta_{2}, U(C, \theta)$,

*Metals and Ceramics Bivision. 
and $U C_{2}$ finely dispersed in a carbon matrix. The kernel is surrounded by a porous buffer coating of pyrolytic carbon to provide void space for gaseous fission products and to prevent damage to outer coatings by high energy fission fragments. The coatings over the buffer are a layer of SiC sandwiched between two layers of high density pyrolytic carbon (low temperature isotropic-LTI). These layers are more dense than the buffer coating and give needed strength for retention of fission products. Bisocoated particles containing the fertile $\mathrm{ThO}_{2}$ kernels have onl $\dot{y}$ buffër and LTI coatings of pyrocarbon. Preparation of the fissile kernels for coating and deposition of the coatings on the particles is done by a fluid-bed technique $(1,2)$.

A time-of-flight mass spectrometer (TOFMS) has been added to the facility to monitor, in-line, the effluent gas stream and to study the fuel preparation reactions. The purpose of these studies is to optimize conditions for the production of sound HTGR fuel particles and assure occupational and environmental safety from possibly hazardous pollutants which are produced. From these TOFMS analyses, it may be possible to determine reaction mechanisms and kinetics that will better define the processes and aid in the elucidation of the reactions. When any hazardous chemicals in the effluents are specifically identified, one may be able to devise schemes for their disposal.

\section{EXPERIMENTAL EQUIPMENT}

The fuel particle coating facility and its auxiliary equipment have been described previously (1). Sampling lines have been attached to this facility so that gas samples can be pumped continuously with a Model $4 \mathrm{~K}$ Neptune Dyna-Pump (Neptune Products, Inc., Dover, N. J.) to the TOFMS from any one of three sampling points $(A, B, C)$ as shown in Figure 1 . The 
sampling. lines are 1/4-inch (nominal 0.0.) stainless steel tubing wrapped with heating tape and maintained at $200^{\circ} \mathrm{C}$ to prevent condensation of the volatile reaction products.

The inlet and manifold systems of the TOFMS were modified. The original gold foil leak was replaced with a 3-foot section of crimped 0.003-inch $(0.076 \mathrm{~mm})$ I.Q. nickel tubing to form a capillary leak. Argon flowing through this fixed leak produced a pressure of about $1.0 \times 10^{-6}$ Torr in the TOFMS. The inlet tube was extended into the cavity of the ion source to increase the sensitivity. The flight tube was heated to about $100^{\circ} \mathrm{C}$ with a flexible heating cable. As shown in Figure 1 , the filters $F_{4}$ and $F_{5}$ were nickel disc filters. which were added to prevent plugging of the capillary leak. The sampling lines were heated and purged with argon for at least one hour before process samples were analyzed.

The TOFMS was operated either in the scanning or sequencing mode. The scanning mode permits scans from mass 1 to 1000 or any segment thereof at a rate up to 20,000 spectra per second. The sensitivity is rated at about $1 \mathrm{ppm}$ for hydrocarbon gases; this will vary depending upon the particular. analysis. The resolution ( $M / \Delta M$, where $M$ is the maximum mass which can be resolved from the neighboring mass $M \pm \Delta M$ at $10 \%$ from baseline for positive ions) was measured to be 420 for $\mathrm{Hg}^{+}$, and this varies according to the scanning procedure. The sequencing mode can monitor any six selected masses by jumping from one mass to another in a repeating cycle. Two readout systems are used: an oscilloscope and an LCR Telex recorder (Midwestern Instruments, Tulsa, Oklahoma) with three sensitivity levels. 
3. EXPERIMENTAL MATERIALS AND PROCESS PROCEDURES

The starting material for microsphere fuel particle preparation is a weak acid ion exchange resin (WAR) loaded with uranyl ions $(\underline{3}, \underline{4})$. The resins used were Amberlite IRC-72 (Rohm and Hass) and Duolite C-464 (Diamond-Shamrock). These resins are acrylic acid polymers crosslinked with divinylbenzene and ethylvinylbenzene. The loaded resins contained about $47 \%$ uranium when fully dried.

The first step in the fuel particle preparation is carbonization of the uranium-loaded WAR. A bed of WAR microspheres fluidized with argon is heated at a programmed rate to carbonize the resin and form a microsphere of essentially $\mathrm{UO}_{2}$ in a carbon matrix (2). Usually $1-2 \mathrm{~kg}$ of uranium-loaded resin was fluidized with $1-3 \mathrm{scfm}\left(0.028-0.085 \mathrm{~m}^{3} / \mathrm{min}\right)$ argon and heated at a rate of $2^{\circ} \mathrm{C} / \mathrm{min}$ up to $600^{\circ} \mathrm{C}$ and then at a faster rate $\left(71 / 2^{\circ} / \mathrm{min}\right)$ to $800^{\circ} \mathrm{C}$, at which temperature the furnace was held for 15-30 minutes. Gaseous pyrolysis products were monitored from sample ports $A$ and $B$ (Figure 1 ), and mass spectra were recorded from $\mathrm{m} / \mathrm{e} 2$ to 184 every three minutes throughout the heating period. The mass spectral scans were manually converted to graphs of relative concentration of specific ions versus temperature. The profiles of these graphs gave indications of the temperature at which reactions occurred during the carbonization. Approximately one-third of the weight of the loaded resin is lost during carbonization.

Reaction temperatures for the carbonization process and other processes were measured at the outer surface of the carbon liner of the furnace by optical pyrometry. Therefore, the recorded temperature was somewhat higher than the actual resin bed temperature, and this temperature 
differential varied depending on the argon flow rate, size of the resin batch, temperature, and rate of temperature rise.

The nominal reaction during resin conversion (2), the second step in fuel particle preparation, is essentially $\mathrm{UO}_{2}+4 \mathrm{C} \rightarrow U \mathrm{C}_{2}+2 \mathrm{CO}$. This reaction was carried to various degrees of completion. The product of the conversion step is a mixture of $U \mathrm{O}_{2}, U(C, 0)$, and $U C_{2}$ with an excess of carbon. The oxygen content or extent of conversion of the converted fuel kernel influences the irradiation performance of the fuel particles $(\underline{5}, \underline{6})$. The percent conversion can be regulated by argon flow rate, batch size, and heating time at a given temperature. Batches of carbonized WAR, fluidized with argon, were converted by heating the particles for various lengths of time at $1600-1800^{\circ} \mathrm{C}$. During the heating the TOFMS was repetitively scanned from $\mathrm{m} / \mathrm{e} 2$ to 50 at $25-\mathrm{sec}$ intervals. The sequencer mode of the TOFMS was also used in some experiments. M/e's $2,18,28,32$, and 44 only were monitored in this mode. These data were converted to relative concentration of a specific ion versus temperature graphs as previously described in the carbonization step.

After the desired kernels are prepared, they are encapsulated in a series of coating processes (ㄱ). The coating processes are deposition processes involving pyrolysis of selected organic compounds (chemicalvapor-deposition, CVD) in a fluidized-bed of microspheres. The innermost. coating next to the converted kernel is a buffer coating ofinporous:pyrocarbon made from the pyrolysis of acetylene. The density of thi's carbon can be varied by dilution with helium or argon in the gas stream, by changing the deposition temperature, etc. This carbon coating process is completed in a short period of time ( 1.5 to $4 \mathrm{~min})$; therefore, the speed of TOFMS is 
useful in monitoring the masses repeatedly. In a typical buffer coating run, $572 \mathrm{~g}$ of carbonized and converted WAR material was heated to $1350^{\circ} \mathrm{C}$ in a bed fludized with.argon. The gas flow was switched to 4 scfm $(0.113$ $\left.\mathrm{m}^{3} / \mathrm{min}\right)$ acetylene plus $1.6 \mathrm{scfm}\left(0.045 \mathrm{~m}^{3} / \mathrm{min}\right)$ helium for 1 minute and 42 seconds. Mass spectra were taken repetitively at 9-second intervals from mass 2 to 47.

The second coating (LTI) is a pyrocarbon coating of more dense carbon, the purpose of which is to retain the fission products. One coating gas mixture which we monitored was $1.1 \mathrm{scfm}\left(0.031 \mathrm{~m}^{3} / \mathrm{min}\right)$ acetylene, $0.9 \mathrm{scfm}$ $\left(0.026 \mathrm{~m}^{3} / \mathrm{min}\right)$ propylene, and $2 \mathrm{scfm}\left(0.057 \mathrm{~m}^{3} / \mathrm{min}\right)$ helium. The elapsed time for coating was 6.8 minutes and the temperature was $1275^{\circ} \mathrm{C}$. The same monitoring procedure was used as that for the buffer coating process.

For Triso-coated fissile-bearing particles, a coating of SiC is added over the inner LTI coating to give enhanced retention of metallic fission products. The CVD reaction for the deposition of SiC is the pyrolysis of methyltrichlorosilane: $\left(\mathrm{CH}_{3} \mathrm{Cl}_{3} \mathrm{Si}\right)$ in the presence of hydrogen. Only one SiC coating run was monitored with the TOFMS. Meaningful mass spectral data were not obtained because the $H C 1$ evolved in copious quantities reacted with the stainless steel sampling lines and TOFMS metal surfaces. Until a better sampling procedure can be devised, no further in-line monitoring of SiC coating will be performed.

The outer LTI coating process was also monitored, and the spectral data were very similar to those of the inner LTI coating.

The final step in the fuel preparation process is particle annealing. The particles are fluidized with argon and heated at $1800^{\circ} \mathrm{C}$ for 30 minutes. There was no observable evolution of material in this step. It has been 
noted that there is a $0.3 \%$ weight loss during annealing which is presumably hydrogen ( 8 ), but because of the insensitivity of the TOFMS to $\mathrm{H}_{2}$, this small amount was not detected.

\section{RESULTS AND DISCUSSION \\ 4.i Cärbonizatión}

Resin carbonization has been repeatedly monitored under various heating conditions. The pyrolysis of polyacrylic acid, which is the basic polymer in IRC-72, has been studied by several investigators $(\underline{9}, 10,11)$. The consecutive steps of degradation of polyacrylic acid include the following: dehydration to the anhydride, the formation of cyclic ketones and unsaturated compounds, evolution of $\mathrm{CO}_{2}$, and fragmentation of the polymer. IRC-72 loaded with uranyl ions would not necessarily be expected to decompose in the same manner. The presence of uranyl ions may eliminate the possibility of anhydride formation, and possibly act as a catalyst for more random fragmentation. The thermal degradation of Amberlite IRC-50 which is similar to IRC-72 has been studied by Marinov and Mitor (12). Their data confirm in many respects the work of the above investigators.

In the present work, water was the first compound detected in the mass spectral scans. Water was very difficult to monitor because the surfaces of the equipment tended to adsorb water, and as a consequence there was a continual memory of water in the spectrum. There were no sharp changes in water concentration with increased temperature throughout the carbonization process. In Figure 2 the water peaks ( $\mathrm{m} / \mathrm{e}=18$ ) cover a large temperature range, and there is no profile sharpness due to the memory effect. However, the data suggest that water is held within the matrix by different 
modes of attachment, perhaps including absorbed and adsorbed water, occluded water, and anion and cation hydrated water. In addition, some water may be liberated by dehydration of polymer molecules. These studies can be improved by decreasing the surface area upon which water can be adsorbed, especially carbon surfaces. Future studies in all metal systems should sharpen the mass spectral profiles and help to distinguish the water types evolved by different mechanisms.

The most voluminous effluent from the carbonization process was carbon dioxide. The rate of $\mathrm{CO}_{2}$ evolution maximized at about $295^{\circ}$ and again at $365^{\circ} \mathrm{C}$ (Figure 3 ). This suggests that there are two types of bonding between uranyl ions and the carboxylic acid ligands in the resin. This has been shown to be true in a study on the mechanism of the sorption of metal ions on carboxylic acid cation exchange resins (13). The infrared study by Chuveleva and coworkers revealed the appearance of two bands at 1640 and $1540 \mathrm{~cm}^{-1}$, and they attribute these bands to the presence of two types of bonds between the carboxyl group and uranyl ions. The band at $1640 \mathrm{~cm}^{-1}$ evidently characterizes the covalent bond, and that at $1540 \mathrm{~cm}^{-1}$ corresponds to a more ionic bond. As the concentration of uranyl ions increased in the resin, the ratio of $1640 \mathrm{~cm}^{-1} / 1540 \mathrm{~cm}^{-1}$ decreased. Cheveleva and coworkers suggest that the first uranyl ions were bonded covalently to the sterically more favorable carboxyl groups. As the uranyl concentration increased, only the more remote carboxyl groups were available, and consequently, this bonding was more ionic. This may account for the twostep decarboxylation of WAR. Yufryakova et al ., continuing the study of the mechanism of the sorption of metal.ions (M) on carboxylic acid (A) cation exchange resins, have shown that two uranyl complexes were formed, 
viz. $\left[M(A)_{3}\right]^{-}$and $\left[M(A)_{2}\right] \quad(14)_{0}$. The stability constant for $\left[M(A)_{3}\right]^{-}$was $8 \times 10^{10}$ and for $\left[M(A)_{2}\right], 4 \times 10^{6}$; however, as the degree of uranium loading in the resin increased, the relative amount of $\left[M(A)_{3}\right]^{-}$decreased. The stabilities of these complexes may affect the rate of decarboxylation and result in the maxima noted at the two temperatures.

Carbon monoxide was another major effluent monitored from WAR degradation during carbonization (Figure 3). Carbon monoxide was evolved simultaneously with $\mathrm{CO}_{2}$ at about $295^{\circ}$ and $365^{\circ} \mathrm{C}$; since $\mathrm{m} / \mathrm{e} 28$ has a fragment contribution from $\mathrm{CO}_{2}$, the intensity due to $\mathrm{CO}$ alone was less than appears below $400^{\circ} \mathrm{C}$ in Figure 3. Above $400^{\circ} \mathrm{C}$ the $\mathrm{CO}$ intensity remained greater than $\mathrm{CO}_{2}$. At these higher temperatures there may be some contribution to $\mathrm{m} / \mathrm{e} 28$ by ethylene and alkane fragments but not from $\mathrm{N}_{2}$ (from air) since no $\mathrm{O}_{2}$ was detected. M/e 12 was also monitored for $\mathrm{CO}$ detection, and its peak height versus temperature profile was similar to m/e 28 but less intense. There was a significant $\mathrm{CO}$ peak at about $650^{\circ} \mathrm{C}$ and another at $1000-1100^{\circ} \mathrm{C}$, which will be discussed later relative to conversion. Immediately following the second $\mathrm{CO}_{2}$ and $\mathrm{CO}$ peaks $\left(375-400^{\circ} \mathrm{C}\right)$, there was rapid evolution of many degradation products. We deduced from the mass spectra that the following compounds were evolved: acrylic acid, S) methane, acetylene, benzene, toluene, isopropylbenzene, methyl styrene, styrene, naphthalene, and many hydrocarbon fragments. Also, hydrogen evolution began after $375^{\circ} \mathrm{C}$ and persisted until it peaked at about $650^{\circ} \mathrm{C}$. Other effluent peaks at about $650^{\circ} \mathrm{C}$ were small and included the following m/e's: $28,16,15,2,91,128,130$, and 152. The compounds pyrolyzed at $650^{\circ} \mathrm{C}$ were probably compounds formed during the dehydrogenation, such as aromatic hydrocarbons. 
The principle reaction during conversion is nominally $\mathrm{UO}_{2}+4 \mathrm{C} \overrightarrow{\mathrm{J}}$ $\mathrm{UC}_{2}+2 \mathrm{CO}$. This carbothermic reduction of $\mathrm{UO}_{2}$ to produce $\mathrm{UC}_{2}$ is not a straightforward stoichiometric reaction $(15,16)$. The phase diagrams for the system U-C-O are complicated and controversial (17, 18). Nevertheless, during the conversion reaction at $1700^{\circ} \mathrm{C}$, the only significant effluent was C0. A graph of peak height: of $\mathrm{m} / \mathrm{e} 28$ versus time is given in Figure 4. Heretofore, the carbonization process has been considered complete at $800^{\circ} \mathrm{C}$; however, with these TOFMS studies, it has been established that further decomposition occurs in the range of $1000-1200^{\circ} \mathrm{C}$ (Figure 4). The most significant effluent peak in this temperature zone was $\mathrm{CO}$. Other compounds found here were $\mathrm{H}_{2}, \mathrm{CH}_{4}, \mathrm{CO}_{2}$, and $\mathrm{H}_{2} \mathrm{O}$. The higher masses were not monitored in this range. It was significant that water was evolved at these high temperatures, and it was probably a product of a Fischer-Tropsch type reaction, which could also produce $\mathrm{CH}_{4}$; i.e., $n \mathrm{CO}+(2 \mathrm{n}+1) \mathrm{H}_{2}+\mathrm{C}_{n} \mathrm{H}_{2 n}+2$ $+\mathrm{H}_{2} \mathrm{O}$.

This preconversion reaction or final carbonization which occurred at $1000-1200^{\circ} \mathrm{C}$ has been studied to determine the nature of the reaction. Many of the process experiments were terminated after carbonization at $650^{\circ} \mathrm{C}$, and the particles removed from the facility and stored under argon. Later the same particles were reintroduced into the furnace and converted to $U C_{2}$. It was speculated that perhaps the reactive particles could have picked up surface water contamination during storage preceding conversion, and with further heating a "water-gas" reaction occurred producing $c 0$ and $\mathrm{H}_{2}$ peaks at $1000-1200^{\circ} \mathrm{C}$. This was disproved by two different experiments. First, experiments have been performed in which the carbonization and conversion reactions have been done sequentially' in one operation without removing the particles from the furnace or cooling between the two 
processes. Evolution of: the same compounds was observed at the same. temperatures in these experiments as in those in which the processes were interrupted. In the second experiment, conversion was stopped at $1170^{\circ} \mathrm{C}$ after the preliminary evolution of $\mathrm{CO}$ and accompanying compounds at 1000 $1170^{\circ} \mathrm{C}$. The particles were cooled in argon and removed from the furnace by the usual procedure and stored under argon. At a later date the same material was introduced again into the furnace, reheated in argon, and the conversion continued. No increases in $\mathrm{CO}$ or other compounds were observed this time at $1000-1200^{\circ} \mathrm{C}$. Therefore, it was concluded that the reaction at" $1000-1200^{\circ} \mathrm{C}$ was one which was inherent to the chemical composition of the particles and not a reaction caused by surface water contamination.

The reaction at $1000-1200^{\circ} \mathrm{C}$ was found to receive some oxygen from the $\mathrm{UO}_{2}$ and was not simply a degradation of the organic components. In the experiment in which the reaction was stopped at $1170^{\circ} \mathrm{C}$, an analysis was made for the $0 / U$ ratio in the starting material which had been carbonized up to $800^{\circ} \mathrm{C}$ and again for the material after heating to $1170^{\circ} \mathrm{C}$ in argon. The mole ratio was 2.05 before heating and 1.93 after heating. Thermodynamic data for $\mathrm{UO}_{2} \pm \times(19)$ indicates an enormous change in oxygen potential between $\mathrm{UO}_{1.99}$ and $\mathrm{UO}_{2.01} \ldots$. For ratios of $\mathrm{O} / \mathrm{U}>2.00$ the excess oxygen assumes interstitial lattice positions while for $0 / U<2.00$ oxygen is bound in anion sites. Interstitial oxygen reacts more readily with $C$ than bound oxygen to form $\mathrm{CO}$ and $\mathrm{CO}_{2}$, and it may be that reduction of $\mathrm{UO}_{2}+x$ to $\mathrm{UO}_{2}$ accourits partially for the reaction at $1000-1200^{\circ} \mathrm{C}$.

\subsection{Conversion}

The width of the broad $\mathrm{C} 0$ peak. during conversion in the range 1600$1800^{\circ} \mathrm{C}$ (Figure 4) was dependent upon the flow rate of argon and the size 
of the batch of carbonized uranium resin particles. A series of conversion experiments were made in which the batch sizes were $0.5,0.85$, and $1.2 \mathrm{~kg} \mathrm{U}$. Each batch was fluidized with 1,2 , and $3 \mathrm{scfm}(0.028,0.057$, and $0.085 \mathrm{~m}^{3} / \mathrm{min}$ ). argon. Figure 4 is a typical curve from one of these nine experiments. The completeness of conversion is illustrated by the abrupt decrease in $\mathrm{CO}$ concentration before the heating period was completed. For $3 \mathrm{scfm}\left(0.085 \mathrm{~m}^{3} / \mathrm{min}\right)$ argonflow, all three batch sizes were completely converted to $U_{2}$ in less than 25 minutes at $1695^{\circ} \mathrm{C}$. For $1 \mathrm{scfm}\left(0.028 \mathrm{~m}^{3} /\right.$ min) argon flow, none of the three batch sizes reacted completely in 25 minutes.

\subsection{Coating}

The TOFMS studies of pyrocarbon and silicon carbide depositions on fuel kernels are still in preliminary stages. The experiments which have been monitored reveal that useful information relative to the mechanism of CVD reactions will be fortheoming. The fact that the TOFMS permits one to monitor fast reactions in real time makes the analysis of precursory species feasible. In some preliminary studies, we have observed that the copious quantity of soot produced during acetylene and propylene pyrolysis has produced some analytical problems. Partial plugging of filters and sampling lines has caused erratic results. Also, many of the products from the pyrolyses were adsorbed by the deposited soot, causing "memory" problems and slower response times.

In addition to the TOFMS monitoring of pyrocarbon and silicon carbide coating reactions in situ, samples of soots and tars taken from the interior surfaces of the coating furnace have been analyzed by gas 
chromatography in combination with mass spectrometry (GC/MS). Two soot samples taken from the crossover pipe between the furnace and the perclene scrubber (20), which is used to remove soot and pyrolysis products from the effluent gas stream, were extracted with methylene chloride, and the extracts analyzed by GC/MS. Several polynuclear aromatic hydrocarbons (PAH) were identified. Lower molecular weight hydrocarbons were not found, undoubtedly, because the soot samples were taken from a high temperature region of the furnace. Among the compounds present, the following were identified: naphthalene, diphenylene (or acenaphthylene), fluorene, anthracene (or phenanthrene), methylene phenanthrene, pyrene, fiuoranthene, benzopyrene, perylene, methylene perylene, and coronene. These compounds were also found in perclene scrubber solutions (21), and the list was very similar to that given by Wolfrum et al. (22) for their soot and pyrocarbon analyses of acetylene and propylene pyrolysis by-products.

The in situ TOFMS studies of the pyrocarbon CVD reaction were monitored for only low masses (up to $\mathrm{m} / \mathrm{e}$ 50), but even there it was obvious that complicated pyrolytic reactions were taking"place. Some typical TOFMS data are shown in Figure 5. Only five masses were monitored here, but other low molecular weight compounds which were evident from other scans were hydrogen, methane, acetylene, ethylene, ethane, propylene, propane, diacetylene, butadiene, and fragments of many others. The fact that $\mathrm{CH}_{4}$ $(\mathrm{m} / \mathrm{e} 16)$ and $\mathrm{C}_{2} \mathrm{H}_{4}$ (m/e 28) appear almost simultaneously with acetylene ( $m / e$ 26) indicates the rapid rate of the pyrolysis reaction. It is interesting to note that hydrogen (m/e 2) appears slightly later. The "memory" problem due to adsorption on soot deposits is illustrated by the persistent concentration of $\mathrm{m} / \mathrm{e} 28$ and $\mathrm{m} / \mathrm{e} 44$ after the coating gas is 
turned off. These are only preliminary data, but they do indicate what we can expect as we study these reactions in more detail in the future.

The mechanism by which carbon is formed in the pyrolysis of gaseous hydrocarbons has been studied extensively by. others (23-29). Not all of their studies are applicable to the fluid-bed coating process that we' are studying, but their hypotheses and experimental results will provide groundwork from which we can look for precursors and reaction products to establish the reaction: mechanism.: A study which has been made and which most nearly coincides with ouri study was that of Wolfrum et al. (22). Their analyses were made only of products collected after the reactions. were complete and not of species as they were formed. Egloff $(\underline{30})$ gives an extensive review of the reactions of acetylene hydrocarbons including acetylene pyrolysis. The pyrolysis of acetylene produces aromatic hydrocarbons by polymerization. Bard et al. (3I) have established that pyrolysis of hydrocarbons in fluidized beds involves dissociation into small fragments which then repeatedly polymerize and dehydrogenate until carbon is deposited. "They studied seven hydrocarbon-helium mixtures; no"matter" which hydrocarbon was used the resulting reactions and products were essentially the same. This supports the hypothesis of Porter (32) that acetylene is a precursor in carbon formation from any hydrocarbion. Gordon et al. (33) have proposed that carbon particles are most likely formed via free radical addition to unsaturates, ultimately forming a polymer. There is evidence that vinylacetylene is one of the first species formed during the thermal decomposition of acetylene. and that a triplet excited acetylene was the initial state for this reaction (34). Benzene may be formed by a Diels-Alder reaction of these species. Benzene, molecules are readily converted to phenyl radicals, or phenyl radicals can be formed from an 
acetylene radical and two acetylene molecules. The continued reaction of phenyl radicals, benzene molecules, acetylene radicals, and acetylene molecules followed by dehydrogenation will produce progressively larger polynuclear aromatic hydrocarbons and finally the structured carbon matrix proposed by Grisdale et al. (35).

The structure of the deposited carbon can be varied by the choice of hydrocarbon gases and their concentration, the type and amount of : diluent, the flow rates of gases, reaction pressure, and temperature. Bokros (36, 37), Bard et al. (31); and Lackey et al. (38) have described the effect of coating variables on density and microstructure of pyrolytic carbon deposits. Further experiments are planned to correlate these variables with the reaction products in fluidized-bed coating procedures with the TOFMS.

\section{CONCLUSIONS}

The feasibility of using a TOFMS for in-line monitoring of effluents from HTGR fuel particle preparation processes has been demonstrated. The results of these preliminary experiments indicate that a better understanding of reaction mechanisms can be anticipated. The speed of data acquisition and the sensitivity for low concentrations of volatile components makes the TOFMS a useful tool for these kinds of analyses. The TOFMS is also useful in detecting malfunctions in the operating equipment, such as air and water leaks, plugged lines, improper gas flows and concentration mixtures, and faulty valves and pumps. It can demonstrate the effectiveness of the scrubbers to remove certain possibly hazardous byproducts, such as carcinogenic polynuclear aromatic hydrocarbons. 
The thermal decomposition of WAR produces two distinct $\mathrm{CO}_{2}$ evolutions which indicates differences in uranyl ion to carboxylic ligand bonding within the resin matrix. The peaking of certain masses to more than one temperature indicates that as the matrix decomposes, secondary reactions occur and new polymeric compounds are formed which are more stable than the starting materials. The evolution of such compounds as hydrogen, methane, and water at $1000-1200^{\circ} \mathrm{C}$ helps to define the reactions occurring. Monitoring of $\mathrm{CO}$ evolution during the conversion reaction can be used as a measure of the completeness of the reaction and the stoichiometry of the $\mathrm{UO}_{2} / \mathrm{UC}_{2}$ formed. These data will be helpful in determining which batch size of carbonized particles, argon flow rate, and temperature are optimum for conversion.

A1though not many coating experiments have been monitored with the TOFMS, we are optimistic about the possibilities of helping to define the widely studied mechanism for pyrolytic carbon deposition. This will be useful not only for HTGR fuel preparation but also for understanding diffusion flames, combustion processes, the formation of carcinogens from hydrocarbons, and the manufacture of carbon-carbon composite materials. 


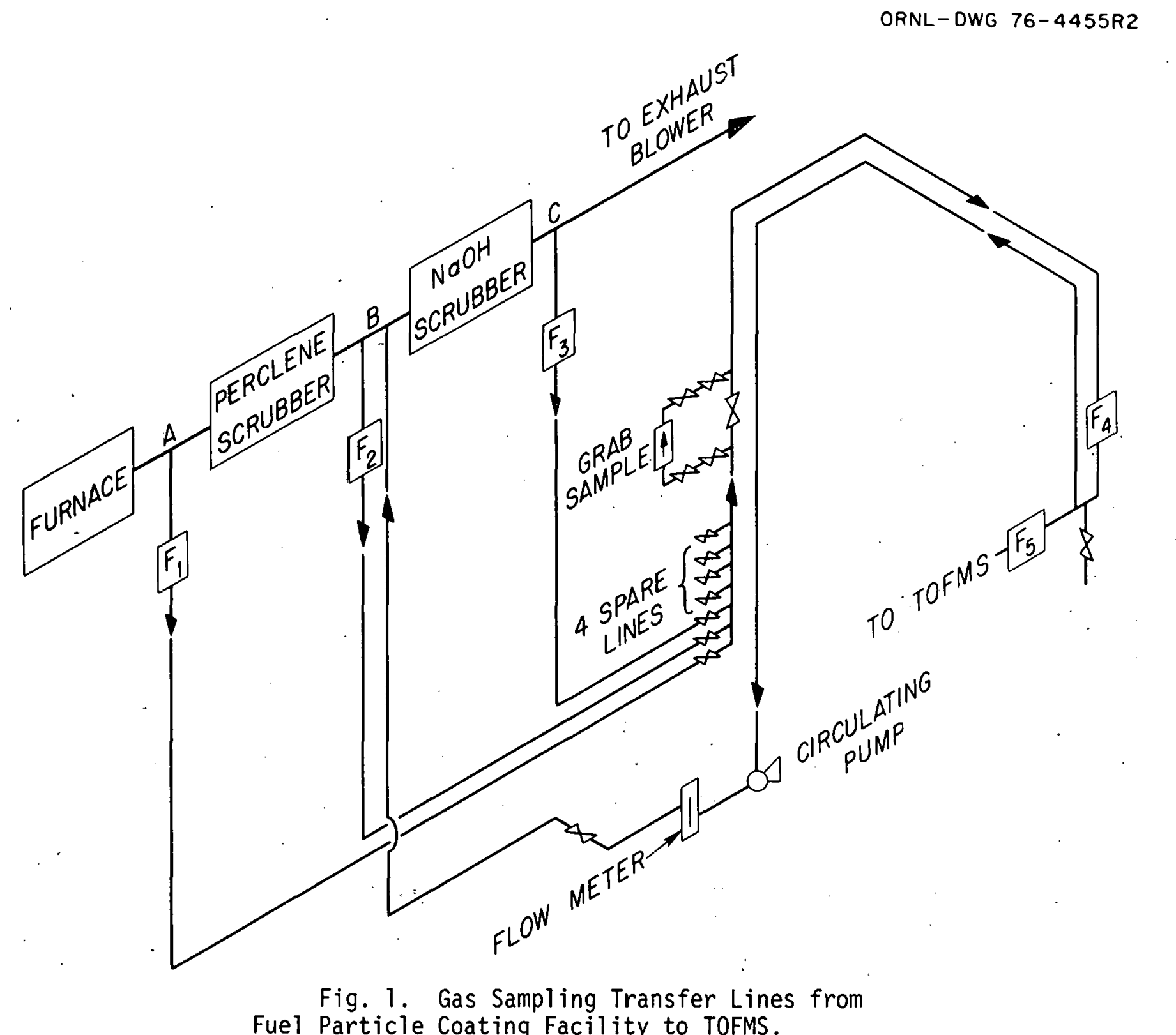




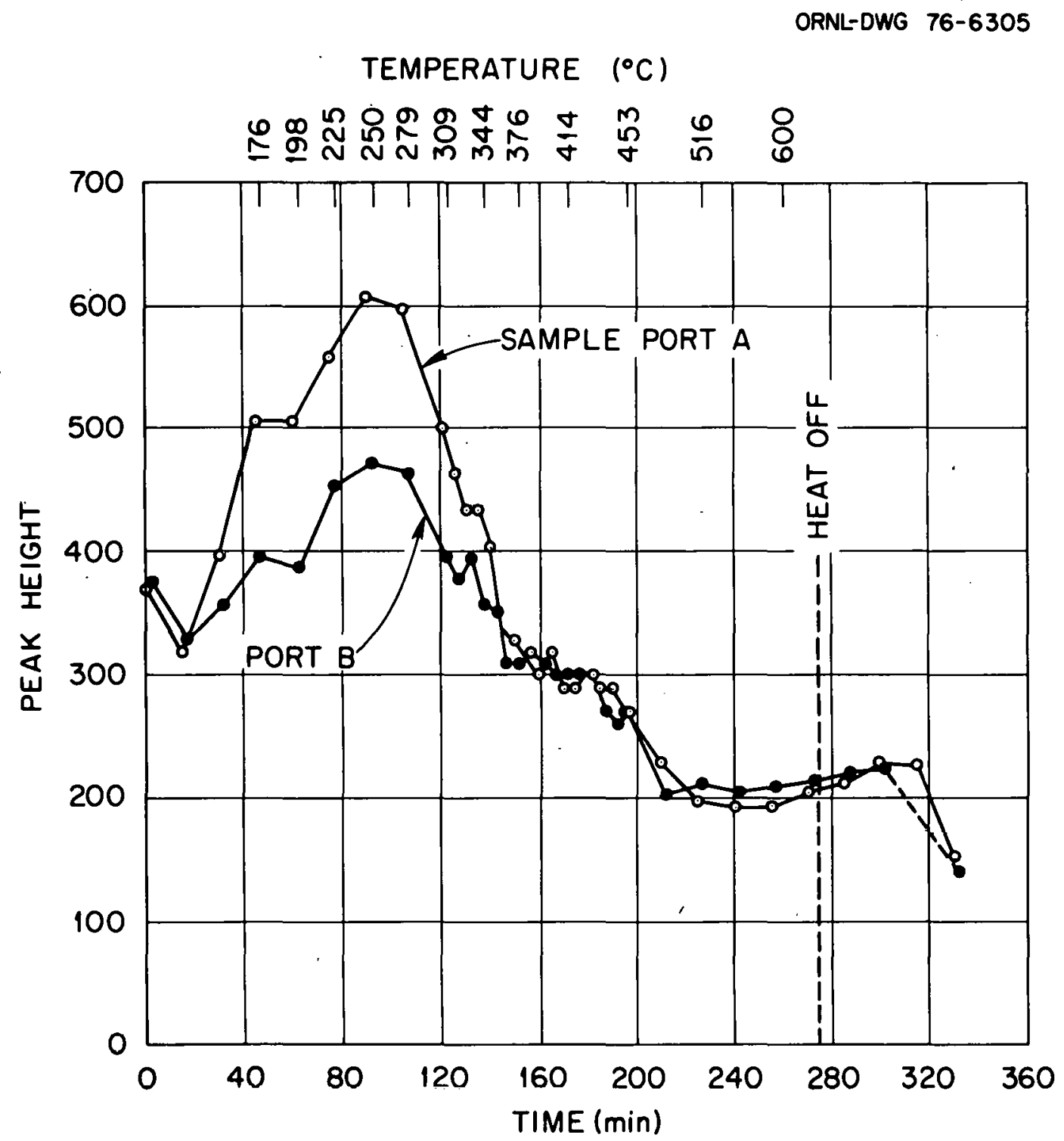

Fig. 2. $\mathrm{H}_{2} \mathrm{O}$ Evolution in Carbonization of Uranium-Loaded Weak Acid Resin. 


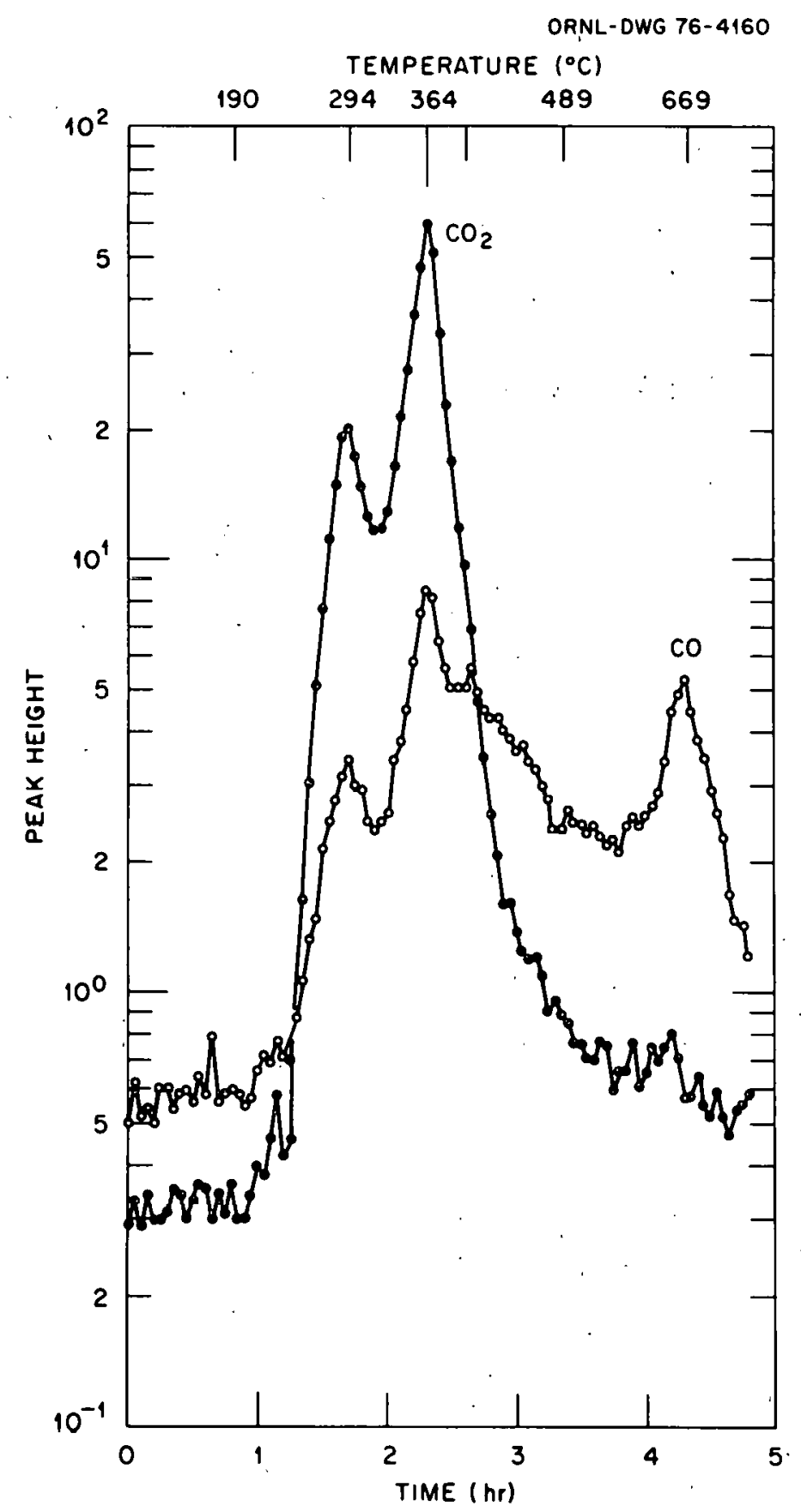

Fig. 3. Carbonization of Uranium-Loaded Weak Acid Resin. 
ORNL-DWG 76-4161

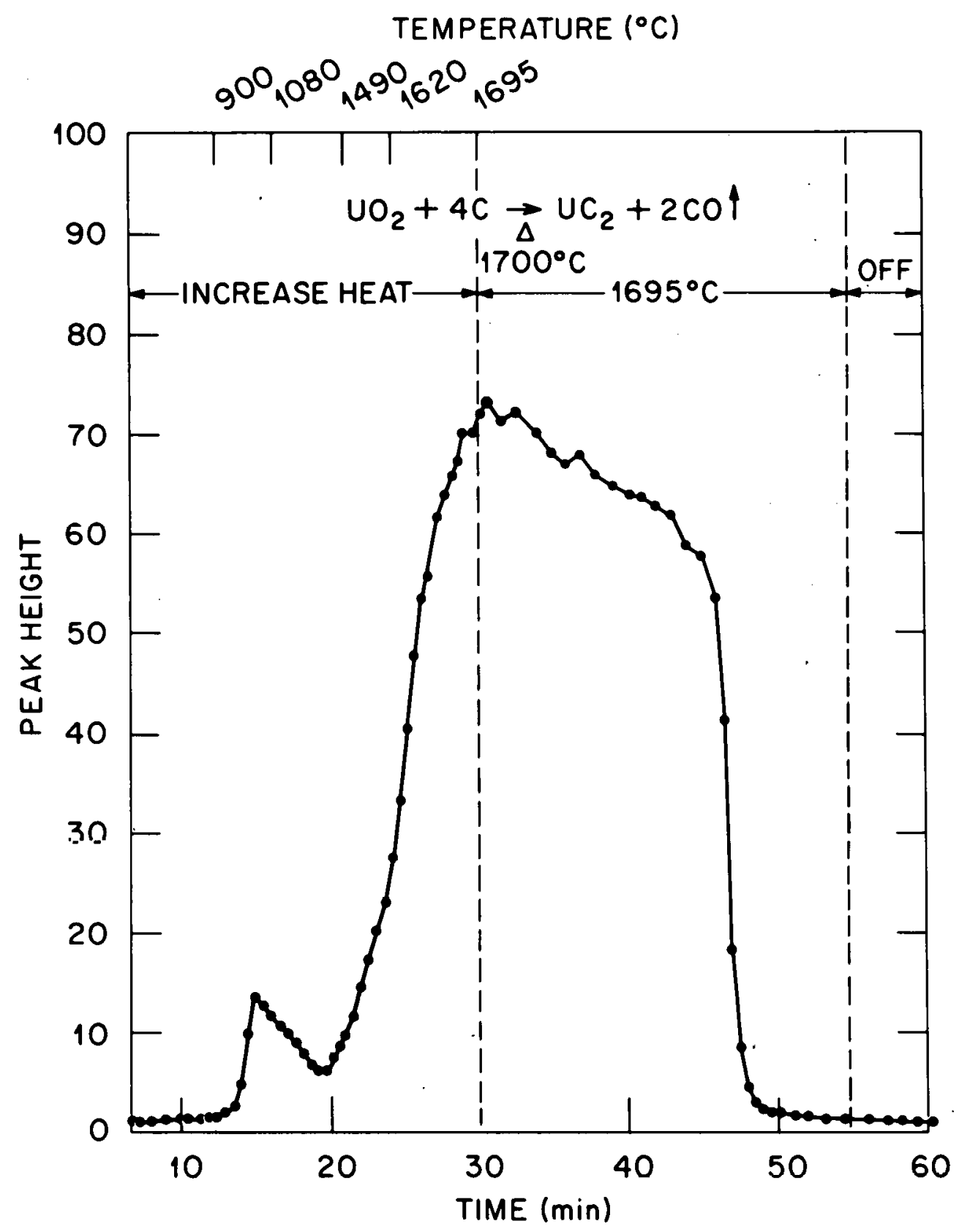

Fig. 4. CO Evolution in Conversion of Uranium-Loaded Weak Acid Resin. 


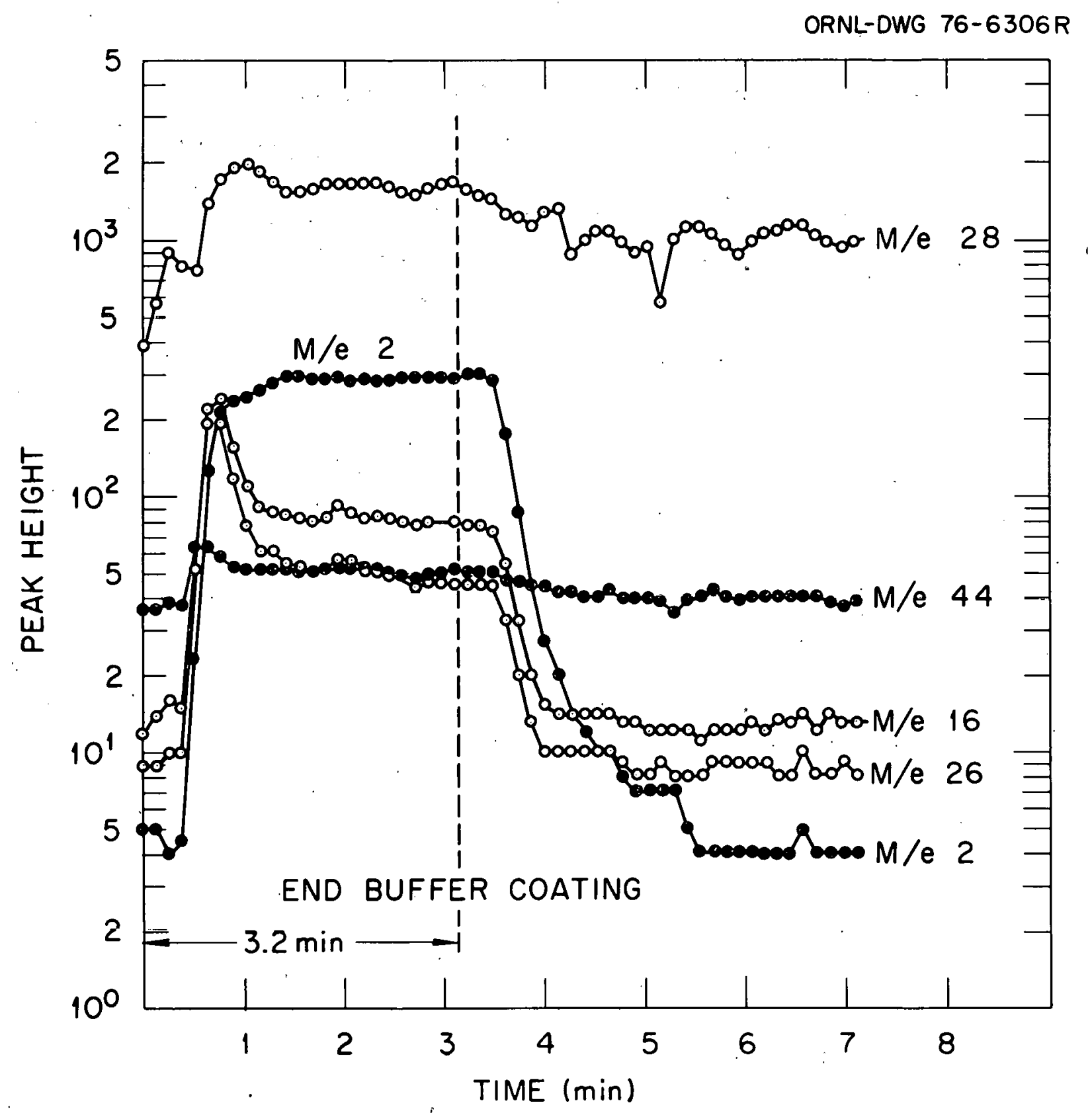

Fig. 5. Evolution of Some Acetylene Pyrolysis Products during Buffer Coating. 


\section{ACKNOWLEDGMENTS}

The authors would like to acknowledge the valuable assistance of H. S. Mckown in maintenance of the TOFMS; C. E. DeVore, W. B. Stines, and C. L. Garrison for the operation of the Fuel Particle Coating Facility; and J. B. Flynn, W. M. Bradley, and J. S. Stewart for processing the data. 


\section{REFERENCES}

1. Wo J. Lackey, W. H. Pechin, C. T. Sanders, F. C. Davis, and F。 J. Furman, Gas-Cooled Reactor and Thorium Utilization Programs Ann。 Progress Report for Period Ending September 30, 1971, ORNL-4760, pp: 45-50.

2. D.R. Johnson, W。 J. Lackey, and J.D. Sease, "The Effect of Processing Variables on HTGR Fuel Kernels Fabricated from UraniumLoaded Cation-Exchange Res in," ORNL-TM-4989 (August 1975).

3. C. B. Pollock and M. B. Silverman, Gas-Cooled Reactor Programs Ann. Progress Report for Period Ending December 37, 1972, ORNL-4917, pp. 90-95.

4. P. A. Haas, K. J. Notz, J. H. Shaffer, "HTGR Fuel Refabrication Development--Res in Loading," GCR Programs Annu. Progr.Rep., Dec. 31, 1973, ORNL-4975, pp。18-22。

5. General Atomic Company, HTGR Base Program, Quant。 Progress Rept. May 31, 1974, Ga-A13030, Pp。9-8 through 9-20.

6. J. A. Contin, J.H. Coobs, W. P. Eatherly, and F。 J.Homan, "HTGR Fuel Irradiations and Post-Irradiation Evaluations," Chap. 7 in GCR Programs Ann。Progress Report, December 31, 1973, ORNL-4975.

7. W. J. Lackey, W. H. Pechin, and J. D. Sease, "Remote Coating of HTGR Fuel Particles," CONF-730601-2 (1973)"

8. W. J. Lackey, personal communication.

9. M. C. McGaugh and S. Kottle, "The Thermal Degradation of Poly (acrylic acid)," J. Polym. Sci., Part B $\underline{5}, 817-20$ (1967).

10. S. Combet and J. Lleras, "Thermogravimetric Study of the Dehydration of Poly (acrylic acid)," C.R.Acad. Sci., Ser. C 270(15), 1280 (1970).

11. A. Franck and $K$. Wuenscher, "Reaction Kinetic Studies on Programmed Isotherm Crossilinkage and Polymer Pyrolys is with Gas Detectors," Int. Congr. Automat. Instrum。Pap。, Rubber Plast. Inc., Pap。, Antwerp F4/13 pp. Oct。1966。C.A。69: 19,737S (1968)。

12. V. Marinov and $B$. Mitov, "Thermooxidative Degradation of a Polystyrene Sorbent and of a Methacrylic Acid Polymer," Jo of Thermal Analys is $7,95-110$ (1975).

13. E. A。 Chuveleva, N。K. Yufryakova, P. O. Nazorov, and $K_{0} V_{0}$. Chumutov, "An Infrared Spectroscopic Study of the Mechanism of the Sorption of Metal Ions on Complex-Forming Resins. II. Infrared Spectra of Carboxylic Acid Resins Containing Uranium," Russ。J.Phys.Chem。44, 1125-1129 (1970)。 
14. N. K. Yufryakova, E. A. Chuveleva, P. P. Nazarov, and K. V. Chmutov; "The Mechanisms of the Sorption of Metal Ions on Carboxylic Acid Cation-Exchange Resins. XII The Formation of a Mixture of Urany 1 Complexes of the Type $\left[M(A)_{3}\right]^{-}$and $\left[M(A)_{2}\right]$," Russ.J. Phys: Chem. 46 , 702-704 (1972).

15. J. F. A. Hennecke and H. L. Scherff, "Carbon Monoxide Equilibrium Pressures and Phase Relations during the Carbothermic Reduction of Uranium Dioxide," J. Nucl. Materials 38, 285-291 (1971).

16. J. M. Leitnaker and T. G. Godfrey, "Thermodynamic Properties of Uranium Carbides via the U-C-O System," J. Chem. Eng. Data 11, 392394 (1966).

17. P. E. Potter, "The Ternary Systems Uranium-Carbon-Oxygen and Plutonium-Carbon-Oxygen, and the Quaternary System Uranium-PTutoniumCarbon-0xygen," J. Nucl. Materials 42, 1-22 (1972).

18. R. F. Stoops and J.V. Hamme, "Phase Relations in the System UraniumCarbon-0xygen," J. Am. Ceramic Soc. 47, 59:=62 (1964).

19. T. L. Markin, V. J.Wheeler, R. J. Bones, "High Temperature Thermodynamic Data for $\mathrm{UO}_{2} \pm x$," J. Inorg. Nuci. Chem. 30, 807-817 (1968).

20. W. J. Lackey, J. D. Jenkins, F. J. Homan, and R. S. Lowrie, "Assessment of Coater Size for the Fuel Refabrication Prototype Plant," ORNL-TM-4567 (July 1974), p. 12.

21. W. T. Rainey, Jr., personal communication.

22. E. Wolfrum, J. Rottmann, H. Nickel, "Identification of Pyrolysis By-Products in Fluidized Bed Soot and Pyrocarbon," Z. Anal. Chem. 268, 19-25 (1974), GERHTR-102.

23. E. Gyarmati, K. Koizlik, P. Krautwasser, H. Luhleich, H. Nickel, and H. A. Schulze, "Pyrocarbon, an Important Material for High-Temperature Gas-Cooled Reactors," Jul-1052-RW, GERHTR-111.

24. K. I. Syskov and E. I. Jelikhovskaya, "On the Formation and Composition of Pyrolytic Carbon," Carbon 5, 201-203 (1967).

25. R. 0. Grisdale, "The Formation of Black Carbon," J.Appl. Phys. 24, 1082-1091 (1953).

26. S. K. Ray and R. Long, "Polycyclic Aromatic Hydrocarbons from Diffusion Flames and Diesel Engine Combustion," Combustion and Flame 8, 139-151 (1964).

27. H. Luhleich, L. Sutterlin, P.Pflaum, and H. Nickel, "Massenspektrometrische Untersuchung der Gaszusammensetzung Wahrend der Bildung von Pyrokohlenstoff aus Methan," Z. Ana1。Chem。260, 220-229 (1972)。 
28. D. R. Dugwell and P. J. Foster, "Carbon Formation from Methane in Combustion Products," Carbon 11, 455-467 (1973).

29. H. B. Palmer, A. Voet, and J. Lahaye, "Mass Spectra of Hydrocarbon By-Products in the Formation of Carbon Blacks, " Carbon $\underline{6}, 65-70$ (1968).

30. G. Egloff, "Reactions of Acetylene Hydrocarbons," Reactions of Pure Hydrocarbons, American Chemical Soc. Monograph, Reinhold Publishing Corp., New York, pp。395-477 (1937).

31. R. J.Bard, H. R. Baxman, J. P. Bertino, and J. A. O'Rourke, "Pyrolytic Carbons Deposited in Fluidized Beds at 1200 to $1400^{\circ} \mathrm{C}$ from Various Hydrocarbons," Carbon 6, 603-616 (1968).

32. G. Porter, "Carbon Formation in the Combustion Wave," Fourth Symposium (International) on Combustion, p. 248. Wilitiams and Wilkins: Baltimore (1953).

33. A. S. Gordon, S. R. Smith, J. R. McNesby, "Study of the Chemistry of Diffusion Flames," Seventh Symposium (International) on Combustion, p. 317 Butterworths: London (1959).

34. V. K. Sarkisyan, "Thermal Decomposition of Acetylene under Adiabatic Conditions," Vses. Konf. Kinet. Mekh.Gazofazn. Reakts., 2nd 16-17 (1971), C.A. 78: $29010 Z$ (1973).

35. R. 0. Grisdale, A. C. Pfister, and W. van Roosbroeck, "Pyrolytic Film Resistors: Carbon and Borocarbon," Bell System Tech. J., 30, 271-314 (1951).

36. J. C. Bokros, "The Structure of Pyrolytic Carbon Deposited in a Fluidized Beds," Carbon 3, "17-29: (1965).

37. J. C. Bokros, "Variation in the Crystallinity of Carbons Beposited in Fluidized Beds," Carbion 3 201-211 (1965)。

38. W. J. Lackey, J. D. Sease, D. A. Costanzo, and D. E. LaValle, "Improved Coating Process for High-Temperature Gas-Cooled Reactor Fuel," Trans.Am.NuCl.Soc., Vo1.22, pp. 194-195 (November 1975). 


\section{THIS PAGE}

\section{WAS INTENTIONALLY LEFT BLANK}


ORNL/TM-5579

Dist. Category UC-77

INTERNAL DISTRIBUTION

1. P. Angelini

2. R. L. Beatty

3. R. A. Bradley

4. D. C. Canada

5. A. J. Caputo

6. J. A. Carpenter

7. J. A. Carter

8. J. H. Coobs

9. L. T. Corbin

10. D. A. Costanzo

11. R. G. Donnelly

12. W. P. Eatherly

13. F. J. Homan

14. J. D. Jenkins

15. D. R. Johnson

16-17. P. R. Kasten

18. J. E. Mack

19. W. J. Lackey, Jr.

20. D. A. Lee
21-22. A. L. Lotts

23. A. P. Malinauskas

24. K. J. Notz

25. A. R. 01 sen

26. W. H. Pechin

27. W. T. Rainey, Jr.

28. J. D. Sease

29. W. D. Shults

30. D. P. Stinton

31. R. R. Suchomel

32. V. J. Tennery

33. J. E. Van Cleve, Jr.

34. J. R. Weir

35-37. Central Research Library

38. Document Reference Section

39-48. Laboratory Records Department

49. Laboratory Records Department, ORNL RC

50. ORNL Patent Office

\section{EXTERNAL DISTRIBUTION}

51-52. ERDA DIVISION OF NUCLEAR FUEL CYCLE AND PRODUCTION, Washington, D. C. 20545

Director

53-54. ERDA DIVISION OF REACTOR DEVELOPMENT AND DEMONSTRATION, Washington, D. C. 20545 Attn: Director

55-56. ERDA OAK RIDGE OPERATIONS OFFICE, P. O. BOX E, Oak Ridge, Tennessee 37830

Director, Reactor Division

Reserach and Technical Support Division

57-223. ERDA TECHNICAL INFORMATION CENTER, Office of Information Services, P. 0. Box 62, Oak Ridge, Tennessee 37830 For Distribution as shown in TID-4500 Distribution Category, UC-77 (Gas-Cooled Reactor Technology)

224-261. ERDA Exchange Agreements with Germany and Dragon Project. 